The action of light and air was discussed and illustrated, and the relation of nitrifying organisms to the enriching of the soil ; the effect of certain organisms which have the power of taking nitrogen from the atmosphere, and of conveying it to plants, was also illustrated. The history of Spontaneous Generation was touched upon, especially in so far as the study of this will-o'-thewisp had led to the advances in our knowledge of bacteriology.

In relation to disease, the part that bacteria play as ultimate causal factors was described as one of prime importance. If bacteriology had done nothing more for us than draw our attention to the concrete specific bacillus as a cause of cholera, or example, so as to allow us to concentrate our attention on special preventive measures, instead of leaving us to wander in the wilderness of "conditions of soil," of "atmospheric influences," of "epidemic waves," and the like, its value would have been amply demonstrated. "Without undervaluing in the slightest degree the careful observations that have been made by eminent epidemiologists, whose work has a value which can only be enhanced by what can be added to it by the bacteriologist, it was pointed out that since Koch's investigations have been accepted as trustworthy, and as the basis on which preventive measures may be founded, we in this country, at any rate, through our admirably constituted Local Government Board, with its organised staff of medical officers and inspectors, have been able, without resorting to strict quarantine, to deal with the specific cases of cholera that have been brought to, or have appeared on, our shores in a fashion that even a few years ago could never have been anticipated. It was further insisted that whatever great predisposing causes may be at work, whatever subsoil, atmospheric, or other conditions may be necessary for the production of an epidemic disease in our midst, we have ample evidence that without the introduction of a special and specific causal agent from outside, we have never had an outbreak of this specific infective disease. Of course, in every outbreak there were men who came forward to show, on the one hand, that only Koch has right on his side, and, on the other, that all wisdom lies in Pettenkoffer's theory. But few seem to act as if, whatever they may believe, the observations of both should receive serious consideration. Seasonal variations, temperature, drainage, rise and fall of ground water, all play an important part in determining the conditions of growth of bacteria; whilst, on the other hand, bad ventilation and filth, famine and illness, all predispose patients to attack. But without the specific organisms that actually set up infective diseases, no infective diseases will occur. Celsus, the great physician, taught that predisposing causes alone were insufficient to set up disease ; whilst, on the other hand, exciting causes by themselves were powerless to act. But when they came to act in combination, he maintained that they were both sure and far-reaching in the production of disease. The same applies to-day, whether we have to deal with diphtheria, typhoid, cholera, or tuberculosis. Pettenkoffer deals with predisposing causes and conditions, Koch with exciting factors-bacteria. When disease has not yet come amongst us, let us follow Pettenkoffer ; but when it is in our midst, or in our immediate vicinity, Pasteur, Koch and Lister are immediately advanced to the position of more trustworthy guides and leaders.

Sixty years ago, the year of the accession of the Queen to the throne, the proof that the yeast plant was a living organism and the cause of the process of fermentation, was almost comvlete, whilst only a year later the germs of the silkworm disease were observed; but it was not until more than twenty years after that, that Pasteur was able to point out the full import of these discoveries. Pasteur's work on fermentation and on disease, his experiments on attenuation of organisms, on protective inoculation and on curative injection for hydrophobia, have already been referred to, and are so well known that it is unnecessary to do more than mention them. Koch wa able, by his new methods of separating organisms and solid media, to go beyond Pasteur in isolating the anthrax bacillus, and in proving to absolute demonstration the relation of the anthrax bacillus to splenic fever. His ingenious methods of cultivating organisms, of staining them in tissues, and of separating the different species, created a new era in bacteriology.

In our own country we owe to Lord Lister the great advances that have been made in the treatment of wounds, by which thousands of lives are yearly preserved, advances which date entirely from his study of bacteria and bacteriology. Antiseptic surgery, like the antitoxic treatment of diphtheria, is based entirely upon the early researches on bacteriology, and its development has followed most closely the advances made in that subject. "As yet no one can say, that we have reached even a resting-stage, and it behoves all those who desire to see advances made in the treatment and prevention of disease, whether in the department of protection and cure, with which medicine is specially concerned, or in the preventive department, with which you gentlemen as Civil Engineers have to deal, to continue to follow closely every new fact and every fresh theory arising out of new observations, in order that bacteria and the forces with which they are endowed may be made our well-disciplined servants, instead of being allowed to waste their energies as uncontrolled and uncontrollable masters."

\section{THE PASTEUR MEMORIAL LECTURE OF THE CHEMICAL SOCIETY.}

A SPECIAL meeting of the Chemical Society was held on Thursday evening, March 25, when Prof. Percy Frankland, F.R.S., delivered the Pasteur Memorial Lecture. Prof. Frankland commenced his discourse by pointing out that the consideration of Pasteur's work was a subject specially befitting the Chemical Society, inasmuch as he owed the training which enabled him-to master so many and such various problems to that rigorous discipline to which in early years he was subjected in the pursuit of chemistry. Pasteur's interest in this science was exhibited at a very early age, and even when he was a lad at the provincial college of Arbois, his master cherished the ambition that he would one day occupy a chair at the famous Ecole normale in Paris. This hope was well justified, for it was there that Pasteur, as assistant to M. Balard, commenced those epoch-making discoveries which have stimulated researches in, and practically founded, that fascinating and important branch of chemical science known as stereo-chemistry. Perhaps the most conclusive and eloquent testimony which we can have to the profound importance of Pasteur's researches in this direction is the tribute paid to them by one of his greatest followers, Emil Fischer, who acknowledged but a short time since that, despite the immense amount of work which has been subsequently carried out in this field, "there is hardly a new fact of fundamental importance which has been added to his discoveries.'"

It was at the Ecole normale also that Pasteur, many years later, carried out his brilliant researches on the etiology of diseases. Pasteur was led to turn his attention to the study of fermentation phenomena by his removal to Lille, one of the leading industries of the district being the manufacture of alcohol from beetroot and grain; and in his desire to bring the work of his department into touch with local interests, he commenced that classical series of researches which he continued over a period of twenty years. In this field of inquiry he had his first passage of arms with the great Liebig ; it is needless to say how Pasteur emerged victoriously from this contest, and succeeded in demolishing the chemical theory of fermentation processes which had been advanced and supported so eloquently by Liebig and other leading men of science of the day, and building up in its place that theory which the so-called "vitalists" had so long laboured ineffectually to establish. Pasteur's researches on fermentation also proved of enormous commercial benefit to France and the whole world, by indicating improved methods for the manufacture of vinegar, wine, and beer. Moreover, it was in the course of these inquiries that he established that process of preserving liquids by means of heat, now widely known as Pasteurisation. The story of the famous spontaneous generation controversy was told, and Prof. Frankland pointed out how, in pursuing the laborious investigations involved by his entering into this discussion, Pasteur was unconsciously preparing himself for the great work with which his name will always be associated-the inauguration of the modern system of preventive medicine. Already in his researches on diseases in silkworms, undertaken at the pressing request of his friend and former teacher Dumas, Pasteur was specially attracted by the question of contagion; and the valuable experience he gained in this work may be gathered from the fact that in later years, when any one presented himself and begged the privilege of being allowed to work in his laboratory, he used invariabiy to ask them if they had read his volume on silkworm diseases, and tell them that that was the best preparation they could have for working with him.

NO. I 43 I, VOL. 55] 
The five years which Pasteur spent upon this successful, though harassing, inquiry told terribly upon his health, and he was struck down by a paralytic seizure, from the physical effects of which he never absolutely recovered, though the clearness of his intellect was never for a moment impaired. His researches on silkworm diseases, and his long and intimate contact with fermentation phenomena, gradually paved the way for the momentous step which led him, at the already ripe age of fifty-five, to enter upon the study of diseases in the pursuit of which he was to win his most glorious laurels. Prof. Frankland described how Pasteur, after much hesitation, was led himself to embark upon this quest in consequence of his anxiety lest through exaggerated statements and undue haste in drawing conclusions-a tendency exhibited by many who at this time took up the bacteriological study of diseases-a reaction should be provoked, and the new ideas consequently fall into disfavour. Pasteur commenced his campaign by investigating the disease known as anthrax ; but even while carrying on the most elaborate researches on this subject, he was turning in all directions for material to extend his studies on pathological phenomena. He walks the hospitals, armed with sterile vessels, to collect morbid products; he isolates the staphylococcus pyogenes; he visits the Maternity Hospital, and discovers the streptococcus pyogenes, asserting it to be the cause of puerperal fever. But the occupation of discovering pathogenic bacteria, fascinating as it was, could not permanently engross Pasteur's attention, and his ambition, stimulated by the contemplation of Jenner's great discovery, led him to seek a means of securing immunity from those diseases of which the specific viruses had been discovered, similar to that which his great predecessor had secured in the case of small-pox. Pasteur's discovery of a vaccine for fowl cholera was soon followed by vaccines for Rouget de porc or swine measles, and for anthrax, the saving to his country by the use of the anthrax vaccine alone having amounted to no less than $280,000 l$. in the course of the ten years from I884 to 1894. The magnificent triumph which followed the discovery of these vaccines was, however, if possible, eclipsed by the elaboration of a cure for rabies; nearly 20,000 persons have undergone Pasteur's anti-rabic treatment, and the mortality amongst these treated persons has been less than 5 per rooo. The public expression of gratitude for this great discovery, concluded the lecturer, took the form of a general subscription, which rendered possible the foundation of the Institut Pasteur, which its great namesake had long cherished as a dream, and the realisation of which was the delight of his few remaining years ; and here, under the auspices of Duclaux, Roux, Chamberland, and Metschnikoff, the sacred fire kindled by le grand Maître is still burning. Long may this flame be fed within the temple where now rests in eternal sleep that hero of science, whose greatest ambition was to be able, in his last hour, to pronounce the wards, so simple in their form, so boundless in their aspiration, $j$ 'ai fait ce que j'ai pu.

\section{THE DIAMOND MINES OF KIMBERLEY.1}

$\mathrm{IT}^{\mathrm{T}}$ is a standing surprise to the watchful outsider how little attention is bestowed on some of our colonies. For in stance, to the Cape Colony, comprising vast, varied, and productive regions, we have till recently manifested profound ignorance and consequent indifference. When the Cape Colony was first incorporated with the Empire, it was pronounced "a bauble, unworthy of thanks." Yet before the Suez Canal and the Waghorn overland route to India, the Cape, as commanding our road to India, Australia, and China, had a special importance. Even now it presents an alternative route which under conceivable circumstances may be of capital moment.

The high grounds above Cape Town are rich in medicinal health-giving waters. The districts where these springs occur are high-lying, free from malaria, and admirably adapted for the restoration of invalids. It needs only some distinguished power to set the fashion, some emperor, prince, or reigning beanty to take the baths and drink the waters, and the tide of tourists would carry prosperity to Aliwal North, Fraserburg, Craddock, and Fort Beaufort.

From London to Kimberley by the Cape route is about 6700 miles, and is compassed in three weeks, although I would

1 Two lectures delivered at the Imperial Institute, on Ncvember 16 and December $7, \mathbf{1 8 9 6}$, by Dr. William Crookes, F.R.S. warmly recommend any one on pleasure bent to do as my wife and I did-spend a few days at Cape Town-before commencing the tedious railway journey to Kimberley.

The famous diamond mines in the neighbourbood are Kim. berley, De Beers, Dutoitspan, Bulfontein, and Wesselton. They are situated in latitude $28^{\circ} 43^{\prime}$ South, and longitude $24^{\circ} 46^{\prime}$ East. The town itself is 4042 feet above sea-level. Other mines in the neighhourhood are worked for diamonds, but as yet they are unimportant. Kimberley is practically in the centre of the present diamond-producing area. Besides these mines, two others of some importance in the Orange Free State are known as Jagersfontein and Coffeefontein, about sixty miles from the Kimberley diamond region.

\section{KimberLey.}

The surface of the country round Kimberley is covered with a ferruginous red, adhesive, sandy soil, which makes horse traffic very heavy. Below the red soil is a basalt, much decomposed and highly ferruginous, from 20 to 90 feet thick, and lower still from 200 to 250 feet of black slaty shale containing carbon and iron pyrites. These are known as the Kimberley shales; they are very combustible, and in a part of the De Beers mine where they were accidentally fired, they smouldered for over eighteen months. Then follows a bed of conglomerate about Io feet thick, and below the congiomerate about 400 feet of a hard compact rock of an olive colour, called "melaphyre" or olivine diabase. Below the melaphyre is a hard quartzite about 400 feet thick. The strata are almost horizontal, dipping slightly to the north : in places they are distorted and broken through by protruding dykes of trap. There is no water nearer than the Vaal river, about fourteen miles away, and formerly the miners were dependent on rain-water and a few springs and pools. Now, however, a constant and abundant supply of excellent water is served to the town, whilst good brick houses, with gardens and orchards, spring up on all sides. To mark the dizzy rate of progress, Kimberley has an excellent club and one of the best public libraries in South Africa. Parts of the town, affectionately called "the camp" by the older inhabitants, are not beyond the galvanised iron stage, and the general appearance is unlovely and depressing. Reunart reckons that over a million trees have been cut down to supply timber for the mines, and the whole country within a radius of 100 miles has been denuded of wood with the most injurious effects on the climate. The extreme dryness of the air, and the absence of trees to break the force of the wind and temper the heat of the sun, probably account for the dust storms so frequent in summer. The temperature in the day frequently rises to $100^{\circ}$ in the shade, but in so dry a climate this is not unpleasant, and I felt less oppressed by this heat than I did in London the previous September. Moreover, in Kimberley, owing to the high altitude, the nights are always cool.

The approach to Kimberley is deadly dull. The country is almost treeless, and the bare veldt stretches its level length, relieved only by distant hills on the horizon.

\section{TILE PIPES.}

The five diamond mines are all contained in a circle $3 \frac{1}{2}$ miles in diameter. They are irregularly shaped round or oval pipes, extending vertically downwards to an unknown depth, retaining about the same diameter throughout. They are said to be volcanic necks, filled from below with a heterogeneous mixture of fragments of the surrounding rocks, and of older rocks, such as granite, mingled and cemented with a bluish coloured hard clayey mass, in which famous blue clay the imbedded diamonds are hidden.

The breccia filling the mines, usually called "blue ground," is a collection of fragments of shale, various eruptive rocks, boulders, and crystals of many kinds of minerals. Indeed, a more heterogeneous mixture can hardly be found anywhere else on this globe. The ground mass is of a bluish-green, soapy to the touch, and friable, especially after exposure to the weather. I'rof. Maskelyne considers it to be a hydrated bronzite with a little serpentine. Besides diamonds, Moissan has detected more than eighty species of minerals in the blue ground, the more common being :- Magnetite, ilmenite, garnet, bright green ferriferous enstatite (bronzite), a hornblendic mineral closely resembling smaragdite, calc-spar, vermiculite, diallage, jeffreysite, mica, kyanite, augite, peridot, iron pyrites, wollastonite, vaalite, zircon, chrome iron, rutile, corundum, apatite, olivine, sahlite, chromite, pseudobrookite, perofskite, biotite, and puartz. The 